\title{
TOWARDS NEW APPROACHES FOR INTEGRATING PRINCIPLES OF PRECEDENT ARCHITECTURE INTO ENERGY EFFICIENT BUILDINGS IN HOT-DRY CLIMATE
}

\begin{abstract}
A B S T R A C T
Buildings can be designed to require far less energy than today's average. Reducing energy consumption of buildings in hot-dry climates by using natural energy sources to provide comfortable microclimate is the main concern of this study. In this paper design strategies in terms of energy efficiency have been considered based on proper building form, material selection and orientation and by taking advantages of passive cooling strategies and ventilation. The study aims to show that the idea of using natural energy and passive cooling strategies came from the vernacular principles.
\end{abstract}




\section{INTRODUCTION}

Since the last few decades of the 20th Century till now, our planet did warm quickly. The beginning of global warming was caused by fossil fuels being burned to provide energy and emitting plenty of $\mathrm{CO}$. Globally, buildings account for close to $40 \%$ of total end use of energy ${ }^{1}$. In this matter architects and building designers hold the key to turning down the global thermostat and lessen our dependence on fossil fuels. Architects have a moral responsibility to consider whatever may affect the efficiency of the building. Every climate produces certain observed effects on architectural form. Architecture is valuable when it is rooted in the location and the culture of a region and responsible for its surrounding environment. Vernacular responses to every climate conditions embody a wealth of design principles which should be retrieved and applied today. All traditional solutions should be evaluated scientifically before they are discarded or substitutes proposed. The phenomena of the microclimate should be analyzed and new building materials, methods and designs must be tested until the complex relationships among buildings, microclimate and human beings are fully understood ${ }^{2}$. Rational solutions from vernacular architecture should be resurged in contemporary architecture and a comprehension of how they might accomplish truly sustainable building in future should be considered. The work of some proponents of vernacular architectures Such as Hassn Fathy, Paul Oliver, Kamran Diba, etc.,have been mentioned all of whom have demonstrated how vernacular technologies, materials and forms may be applied in contemporary design. Few attempts have been made to investigate the vernacular architecture, but most of existing literatures in this field are introduction or historical materials and do not deal with vernacular techniques in terms of integrating vernacular strategies in contemporary development.

This study is based on a research thesis which has been carried out for the hot and dry climate of Iran. The study first aims to show the advantages of traditional architectural principles in climate responsive design aspect. Secondly it attempts to put forward the rational principles of vernacular architecture of Iran that can be used in energy efficient architectural design.

In this paper climatic design strategies in hot and dry climate were examined and architectural principles in terms of design criteria such as minimizing solar gain inside the building, minimizing conductive heat flow, promoting ventilation, promoting earth cooling, promoting radiant cooling and promoting evaporation were evaluated. In this matter reducing the costs of fossil fuel energy consumption and greenhouse gas emissions by using the renewable energy source was considered. As the most problematic feature of designing in 
hot and dry climate is its harsh summers therefore this study is focusing on the design strategies of the hot summertime.

\section{CLIMATE RESPONSIVE DESIGN IN TRADITIONAL ARCHITECTURE OF HOT DRY CLIMATE}

Climate is a dominant factor in traditional town planning. The climate of a given region plays a great role in designing of a building. In order to design a structure responding to environment all factors that affect the external environment as well as all aspects of internal environment should be considered. Many vernacular techniques are environmentally responsible and sustainable, but nowadays because of the altered lifestyle and ecological situations some of them are no longer properly functioning. In this regard, the challenging issue is to discover essential principles of vernacular architecture and observe the ways to integrate those principles into development progress. Revising traditional techniques which were used in hot-arid climate of central Iran could be a spark to this matter.

One of the greatest examples of climate responsive design in central part of Iran is Boroujerdi-ha house (Fig. 1). The house is built around a central courtyardatrium with windows, doors, arches and other architectural features facing in, rather than out. In winter, the family would gather in the south-facing side of the house which has larger windows to make the best of the winter light and sunshine. Then in summer, more activities would take place in the north-facing side where the windows were smaller. The summer residence is higher than winter residence and the reason for this is because warm air is raised and the cooler air moves to the lower area (Fig. 2). Aspirator and wind catchers were installed in the southern part of the building in order to make better ventilation. Wind catchers were connected to the main living room in the ground floor and connected to cellar in winter residence. In this house Eyvan (porch) and Revak (veranda) are used to create shady and cool living spaces during the day.

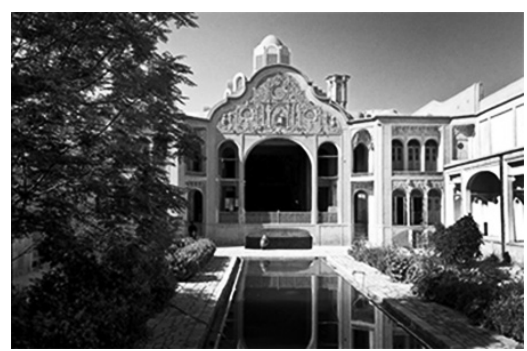

Fig. 1. Boroujerdi-ha house in the Iranian city of Kashan

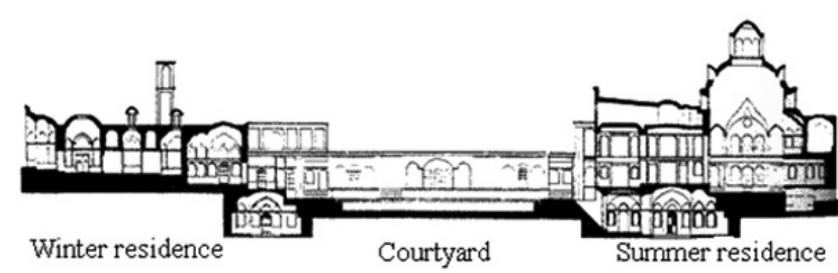

Fig. 2. Notice the difference between the summer and winter residence of the four season house in term of the height of the ceilings 
The most important design parameters that affect the indoor thermal comfort and energy conservation in a building are thermo physical properties of the building envelope, form of the building and architectural elements affecting the indoor climate, the distance between buildings and orientation of the building. When evaluating traditional architectural examples, it can be seen that architects were more sensitive and they accomplished the most suitable design and settlement examples according to each climate condition ${ }^{3}$.

\section{ENERGY EFFICIENT DESIGN STRATEGIES}

IN HOT-DRY CLIMATE

The physical comfort we feel in a building is the result of the heating energy balance between ourselves and the surrounding spaces. To design energy efficient buildings and keep the inside of the building thermally pleasant, solar gain and heat conduction into the building should be minimized while ventilation, evaporation, earth cooling and radiant cooling should be promoted. In the past, architects were obliged to observe these factors, without the benefit of technology and without using polluting, mechanical devices, reliant on electricity. Therefore there should be solutions to render the inside of the buildings thermally comfortable while keeping our environment clean. The purpose of climate responsive and energy efficient design is to minimize the environment pollutions outside the building and reduce the energy cost of maintaining thermal comfort conditions inside the building.

\section{Minimize solar gain}

When solar energy hits a surface, some of the energy is absorbed, some is reflected/, and a portion is transmitted. In order to control solar gain there should be either interception, reflection against solar beams or selecting a proper orientation and size for building shell and openings due to minimizing exposure area to summer sun. These factors can be seen in traditional courtyard houses of hot-dry climate.
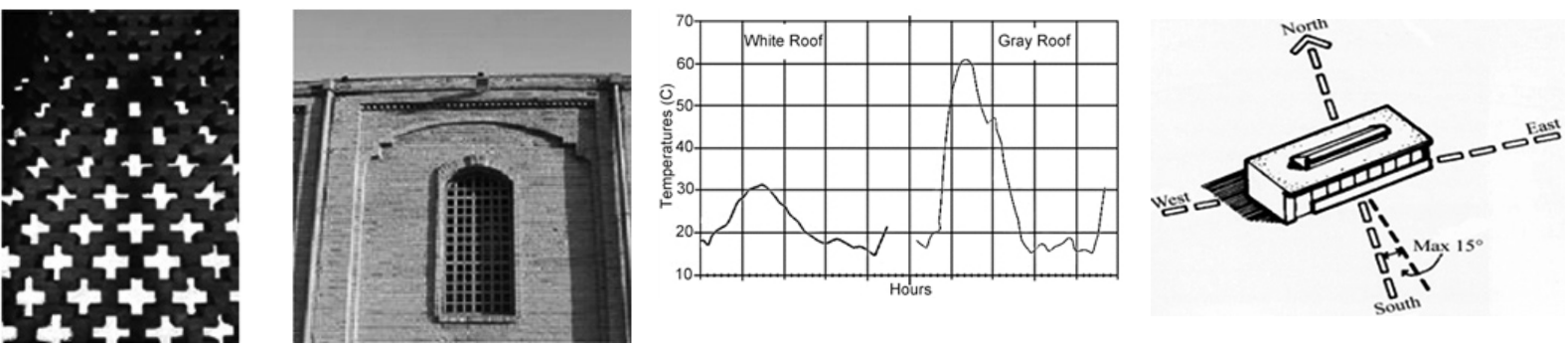

Fig. 3. Traditional reticular window
Fig. 4. Exterior surface temperature of white and gray roofs, same day, two roofs Source [6]
Fig. 5. Building orientation relative to South-north axis 


\section{Interception}

In traditional courtyard houses in hot-dry climates trees as interception devices protect buildings from direct sunbeams and make shady area within the courtyard and on the building walls. Trees collect solar energy using molecular devices, the photosynthetic reaction centers of chloroplasts and use that energy to drive molecular machines, which process carbon dioxide and water into oxygen and molecular building blocks that form the whole plant. A tree is more sophisticated than an aircraft or microchip, created without harmful waste, noise and fumes while consuming its own pollutants ${ }^{4}$. Therefore the nature can teach us to emulate such a process to create flexible behavior in man-made devices. Furthermore, these houses are surrounded by high walls and isolated from the street. During the day, external walls of houses provide shady areas in narrow streets and especially in courtyards.

Walls and particularly windows exposed to summer sun should be shaded by overhangs and shading devices. Windows normally serve three functions: to allow the sunlight in, to let the air in and to provide a view. In the hot and dry climates it is rarely possible to integrate these three functions in a single architectural solution. In the traditional Middle East architecture several solutions were developed which concentrate on each function. The principles of those elements and the combination of them can be used to invent new modern devices in order to afford all advantages of sustainable design. As an instance the window opening called Shabak (a reticular element) was used in traditional houses of hot-dry climate. They block the direct sun rays while the breeze and wind flow is not obstructed (Fig. 3).

A study of the weather condition and the sun angles at various locations between $30^{\circ}$ and $50^{\circ}$ latitude indicates that a standard $76,40 \mathrm{~cm}$ overhang (horizontal projection of $76 \mathrm{~cm}$ located $40 \mathrm{~cm}$ above the top of the window) will provide good sun control on south windows for this range of latitudes, however, when glass doors or tall windows are used it is desirable to increase the overhang to provide more shade 5 .

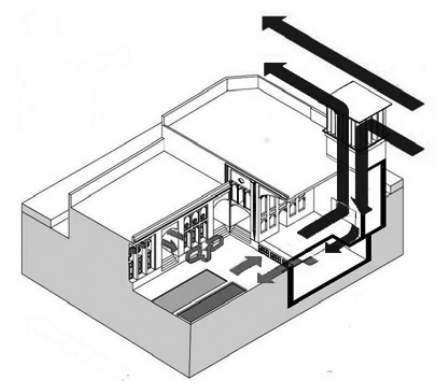

Fig. 6. Function according to the traction and suction

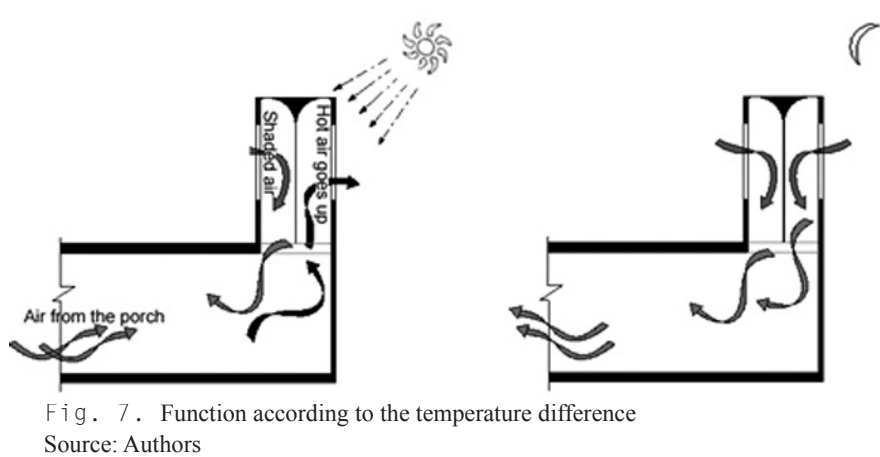

Fig. 7. Function according to the temperature difference Source: Authors 


\section{Reflection}

The exterior colors of the building's envelope chosen by the architect are among the very distinctive features of the building. When a color absorbs the light, it turns the light into thermal energy (heat). The more light a color absorbs, the more thermal energy it produces. Black fabric absorbs all colors of light and is therefore warmer than white fabric which reflects all colors. Figure 4 is the result of experimental studies by Baruch Giovani ${ }^{6}$ which shows the external and internal surface temperatures of a horizontal roof with white and grey colors. The experiment was carried out in Haifa, Israel which has hot-dry climate in summer. A dark roof can be $50^{\circ} \mathrm{C}$ hotter than the ambient air temperature while a white roof will only be about $10^{\circ} \mathrm{C}$ hotter.

\section{Size and orientation of building shell and openings}

With good orientation the need for supporting heating and cooling is reduced, resulting in lower energy consumption. With regard to the sun factor the best lineup for building is along East-West direction. In fact the length of the building should be along East-West axis and the width of the building along North-South axis ${ }^{7}$. The southern wall absorbs the most of sun energy in winter and because the sun is high over the horizon in summer southern wall can be shaded using a relatively small overhang. The eastern and western façades get the undesirable heat in summer therefore they should have less surface exposed to the sun and it is better to cover them with the shadow of trees or nearby buildings. An orientation slightly east of south (typically $15^{\circ}$ east of south) is often more effective, because in this way the eastern façade absorbs lesser sun heats in the summer (Fig. 5).

Windows should be relatively small, particularly on outside walls and must be shielded from direct radiation and glare. Large windows should face north and south. The worst orientation is west-east and it can be used for non-habitable spaces to form a thermal barrier.

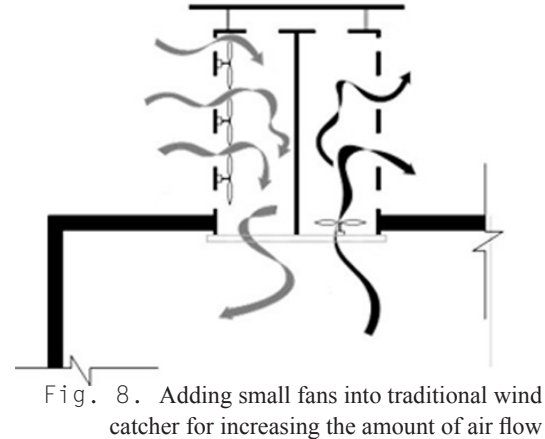

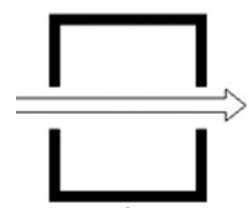

a)

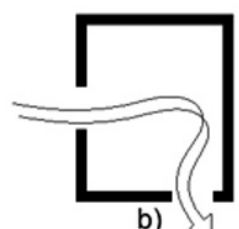

b)

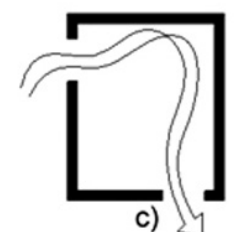

c)

Fig. 9. Direction of draught according to the location of inlet and outlet windows Source: [14] 


\section{Minimize conductive heat flow}

Using materials with the poor heat conductivity will reduce the heat flow through the building in hot-dry climates resulting in reducing energy cost inside the buildings. The process of heat transfer through the building materials described as thermal conduction and the value of heat transfer through a material is the thermal transmission. The thermal conductivity of a material is the amount of heat transfer per unit of thickness for a given temperature difference. Organic materials such as wood tend to be poor conductors. Aerated materials, which have solid conduction paths broken by air or gas gaps such as foam and glass fiber quilt are very poor conductors and they are good insulators as they have low thermal conductivities ${ }^{8}$. In hot-dry climate in the past, vernacular architects made use of materials with poor thermal conductions. In traditional houses of hot-dry regions walls were made out of mud, brick clay or mud clay and plaster of straw and mud with high thickness. Thick and heavy walls made of construction materials with the poor thermal conduction provide cool environment in summer and warm environment in winter (Thermal flywheel effect). Table 1 shows a range of thermal conductivities of some materials.

The heat flow rate is associated with a property of the materials or assembly section known as its conduction and it is defined by the relation:

$$
q=C\left(T_{h}-T_{c}\right) A
$$

Where $\mathrm{q}$ is heat transmission, $\mathrm{C}$ is materials' conductance, $\mathrm{T}_{\mathrm{h}}$ is temperature of the warmer face, $\mathrm{T}_{\mathrm{c}}$ is temperature of the cooler face, and $\mathrm{A}$ is surface area. ${ }^{9}$

\begin{tabular}{|l|l|}
\hline Material & $\begin{array}{l}\text { Therma } 1 \text { conductivity } \\
(\mathrm{W} / \mathrm{mK})\end{array}$ \\
\hline Aluminum & 214 \\
\hline Steel (carbon $1 \%)^{*}$ & 43 \\
\hline Concrete, dense & 1.13 \\
\hline Bricks & 0.73 \\
\hline Water $\left(20^{\circ} \mathrm{C}\right)$ & 0.60 \\
\hline Sand (dry) & 0.30 \\
\hline Wood (oak)* & 0.17 \\
\hline Glass fiber quilt & 0.035 \\
\hline Air* & 0.024 \\
\hline
\end{tabular}

Table 1. Thermal conductivity of some materials

Source: Anon, CIBSE guide, volume A: Thermal properties of building structures (London: CIBSE, 1988), \& http://www.engineeringtoolbox.com/thermal-conductivity-d 429.html. 
Air is one of the best insulators and has low heat transfer characteristics. Walls, roofs and windows which are made up of two or more layers separated by air space provide resistance to heat flow. Highly reflective materials, such as foil, used in air space can reduce the thermal conductivity of windows by over two or three times lesser. The heat which enters through glazed area is trapped and increases the indoor temperature too far above the air outdoors. Therefore the indiscriminate use of glass in hot climate like many of $21^{\text {st }}$ century buildings of hot regions can produce a giant energy consumer and uncomfortable living space.

\section{Promote ventilation}

Ventilation is defined as the act of supplying fresh air and getting rid of foul air. Normally in this process outdoor air is the source of fresh air and the inside air is pollutant air which should be replaced. Building component and technical solutions providing ventilation, both for building and structural cooling, in hot climates were already used in ancient times. For example in Iran, curved-roof air vent systems were incorporated in buildings as early as $3000 \mathrm{BC}$, and wind tower system, the cistern and the ice maker, may have appeared about $900 \mathrm{AD}^{10}$. The wind catcher is a shaft rising high above the building with an opening facing the prevailing wind. It traps the air where it is cooler and at higher velocity and channels it down into the interior of the building ${ }^{11}$. This device is used in the hot arid zones of the Middle East.

A wind catcher operates in two different physical mechanisms: First is the function according to the principle of traction of opening facing the wind and the suction of openings back against the wind (Fig. 6). Wind catchers mainly perform by this mechanism which works under windy condition. In fact a wind catcher takes the fresh air into the building and sends the hot and polluted air out.

The second is the function according to temperature difference. During the day, when the sun hits on the southern face of the wind catcher, the air heats in the southern shaft of the wind catcher, and goes up. This air is taken above through the inner air of the porch. On the other hand in the morning, hot ambient air enters into another shaft of wind tower and it becomes cool when it contacts with the tower walls, which have enough thermal inertia to release at night the heat absorbed during the day. In fact it makes a kind of proportional vacuum inside the building, and takes the cool air of the inner court into itself, so the existing air in the northern opening which was cooled is pulled down too. During the night outside temperature becomes cold, and the cold air moves down through the wind tower. This air becomes warm by walls and parapets 
and then goes up. This circle continues till the temperature of the walls and outside temperature become equal. Therefore at this point night ends and once again the wind catcher acts its function as mentioned above (Fig. 7).

Ventilation appears as a logical and suitable strategy for many types of buildings. Great deal of air flow is needed for summer thermal control of the building in hot and dry climates. Air changes provide people with fresh air to breath, take away pollutants, contribute to the thermal behavior of the building and are an important parameter in the feeling of wellbeing. To increase the amount of air flow through the building few small fans can be added to traditional wind catchers to enhance ventilation within the building (Fig. 8).

Window opening and doors can be oriented to facilitate natural ventilation from prevailing summer breezes. The greatest volume of air will occur when windows are located in the portion of the façade that experiences the greatest pressure differential between them. For a better cross ventilation inlet and outlet size of the windows should be the same size. If they cannot be the same size, the inlet should be smaller to maximize the velocity which has the greatest effect on comfort. Air movement depends on many factors, such as furniture location, exterior planning, wind direction, etc, however some decision can be made for the best ventilation. For example placing windows in line with the direction of air flow on opposite walls will result in a narrow air stem of high velocity (Fig. 9a). By relocating outlet to side wall better ventilation will be produced (Fig. 9b) and by shifting intake window away from center of the façade greater ventilation will occur (Fig 9c) $)^{12}$.

\section{Promote earth cooling (conductive cooling)}

Air is heated mainly by its contact with the earth; the surface soil temperature is about the same as the air temperature with its large annual fluctuations.

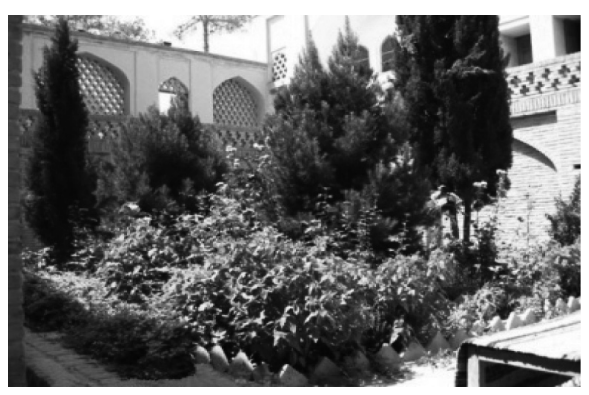

Fig. 10. Profound garden in a traditional Iranian house

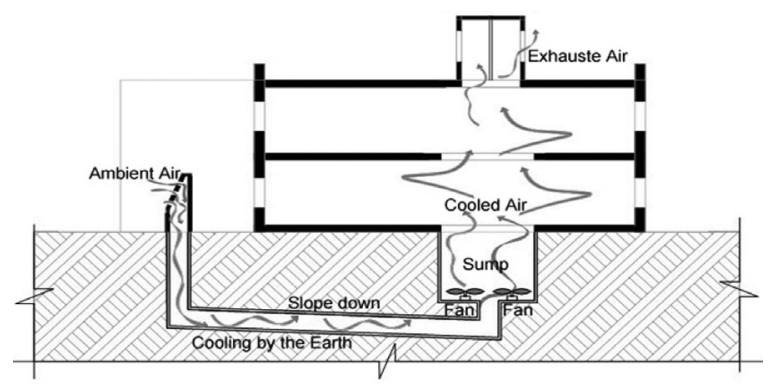

Fig. 11. Indirect earth cooling by means of tubes buried in the ground (Source: Authors) 
However due to the large time lag of earth the soil temperature fluctuates less and less as the soil depth increases at about $6 \mathrm{~m}$ in depth. In traditional house of hot regions in Iran, there was a space development which consisted of a room or rooms at 6-7 meters lower than ground surface and ground floor. These rooms have rather the same temperature in all seasons of the year and it is equal to the average temperature in a year which is about $25^{\circ} \mathrm{c}$.

Since the ground temperature is always below the maximum air temperature, the deep earth can always be used as a heat sink in the summer. When a building is constructed without any excavation, the contact surface of building with ground would be equal to its area but once the excavation is done, meaning that construction of a part of the building into ground is completed, the contact size would be decreased resulting in a cooler interior as compared to the outer ambient temperature in summer. In Hot-dry regions of Iran in some traditional houses the depth of the yards was more than the usual, these yards are called Godal Baghche (Profound garden) (Fig. 10). These profound gardens are covered by plants, trees, and shrubs and by evaporation, cool and fresh air is generated for the upper yard spaces.

Nevertheless the constant deep-earth temperature which is the coolest available air in summer could be a major source as a passive cooling system. A building can be indirectly coupled to the earth by means of tubes buried in the ground. Slope tubes and sump are required to catch condensation. To get the maximum cooling effect the tubes should be buried as deeply as possible to take advantage of that constant, deep-earth temperature which is the coolest available in summer and the soil is more moist during the summer. When cooling is desired, the air is drawn through the tubes into the building. The earth acts as a heat sink to cool the air (Fig. 11) ${ }^{13}$. Despite taking advantage of the earth cooling, the ground of the surrounding area of the structure can be covered by light colored gravels. This covering shades the soil and allows evaporation to occur resulting in a cooler earth ground.

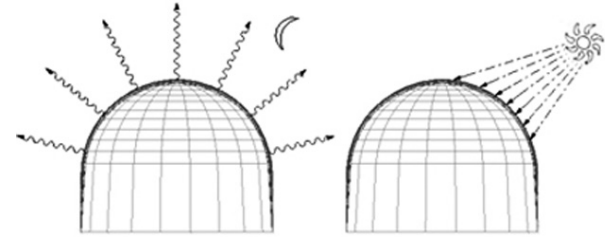

Fig. 12. Low radiant heating during the day and high radiant cooling at the night Source: Authors

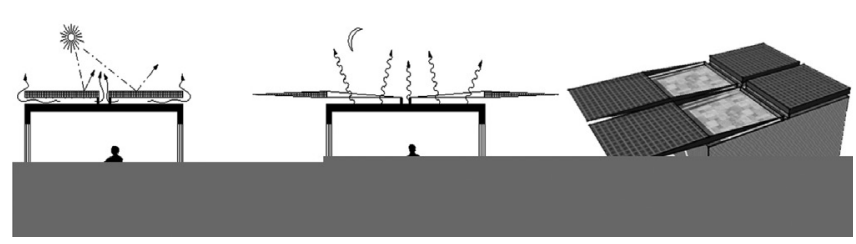

Fig. 13. Movable cover on the roof can reduce radiant heating and increase radiant cooling Source: Authors 


\section{Promote radiant cooling}

Thermal radiation is defined as the transfer of heat energy through space by electromagnetic radiation passing from one object to another without warming the air in between ${ }^{14}$.

In the past, there were several ways of reducing the heat inside the buildings with the benefit of radiant cooling. In traditional architecture of hot and dry climate, architects used deep courtyards and narrow alley with high walls to minimize hours of direct sunlight during the day. However all of the walls radiated to the cold sky during the night. Thus the walls were quite cool by the morning. In addition domed roofs have been widely used in traditional architecture mainly in hot and dry climates and have had an extreme effect on reducing the building's loads. The form of domes presents two different benefits. During the day, always some area of the dome is in shadow while at night full hemisphere sees the night sky (Fig. 12). Thus, radiant heating is minimized while radiant cooling is maximized.

Since the roof has the greater surface exposures to the sky, it is the best location for considering the long-wave radiant cooling. The most efficient approach to radiant cooling is to make the roof itself the radiator. For example a movable cover on the roof can be designed to prevent the heat radiation during the day and at night by removing the cover, the entire roof surface is exposure to the night. Therefore the roof takes full advantage of radiant cooling while radiant heating decreases (Fig. 13). Small gap between the cover and the roof is required to allow heat convection during the day. Solar panels can be stuck on the movable devises to capture solar energy during the day to provide the electricity needed to move the covers. In this matter high thermal mass materials are the best choice for the roofs. The reason for this is because high thermal mass building materials allow heating and cooling air to be stored within the home's roof and perform as a cool storage during the night, thus the next day, can cool inside the building gradually.
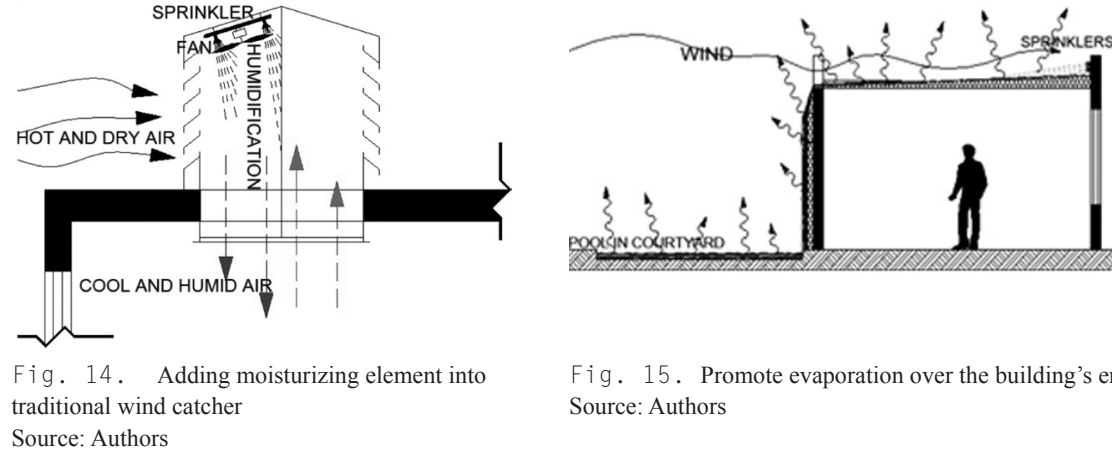

Fig. 15. Promote evaporation over the building's envelope Source: Authors

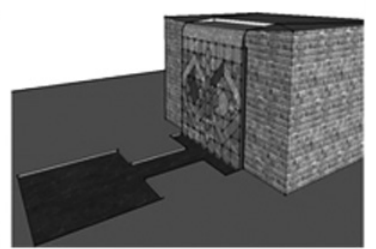




\section{Promote evaporation}

The evaporation of moisture is an important mechanism for cooling of various surfaces. The evaporation of water from surfaces in evaporative coolers is an important method for cooling buildings in arid part of the world ${ }^{15}$. Thus traditional wind catchers can be turned into evaporative coolers. This is possible by adding a pump and a fan directly in the entrance duct. The fan is used to flow greater amount of air into the building and the pump moisturizes the dry air (Fig. 14). To maintain comfort, a high rate of ventilation is required during the day. This phenomenon which cools the indoor air through the increasing humidity is called direct evaporative cooling system. Traditional court yard houses with central pool in hot and dry climate provide comfortable weather condition within the house. Once water of the pool evaporates into the air, the temperature decreases. The amount of heat needed to vapor water is taken from the surrounded air within the yard, hence air itself becomes cooler. Furthermore by evaporation, the moistures in the air decrease and humidity of dry air goes up resulting in a comfortable weather condition for dry climate.

Evaporation can be highly promoted by means of sprinklers and a small pond on the roof. A slight slope is required on the roof to lead the water into the pond. Thus the roof is always wet and additional water is kept in the pond. Water from the pond is directed to the court yard over a solid surface. This surface keeps the wall safe from water penetration. Then water bunches up in the central pool in court yard. At all times in this process water is being evaporated and the surrounding area is getting cold and moisturized because of evaporation (Fig. 15).

\section{CONCLUSION}

Before using any technology and mechanical devices to render the inside condition of the buildings pleasant vernacular solution should be examined. The paper pointed out to the simple strategies that can be impressively improving contemporary buildings of hot and dry climate without the benefit of high technology devices. Strategies that can struggle with harsh climate of hot and dry regions such as interception from the sunbeams before getting heat and using cooling devices, rising the amount of air flow and ventilation, moisturize the dry air.etc. Primitive and vernacular dwellings and settlements of the past can be used today in their present form and should be altered as little as possible. Traditional architects of the hot and dry climate presented numbers of logical methods into the building to provide thermal comfort for resident .To decrease the cost of the today's energy and in order to keep our environment clean, those methods can be evaluated and implemented into the contemporary buildings. If traditional solutions are not sufficient, then they can be integrated with the minimum technology. 
Jens Laustsen, Energy efficiency requirements in building codes, energy efficiency Policies for new buildings (Paris: International energy agency, 2008), http://www.iea.org/efficiency/CDEnergyEfficiencyPolicy2009/2-Buildings/2-Building\%20Codes\%20for\%20COP\%202009.pdf Hassan Fathy, Natural energy and vernacular architecture; principles and examples with the reference to Hot Arid climates, (Chicago and London: University of Chicago press, 1986).

3

G. Manioglu and Z. Y1lmaz "'Energy efficient design strategies in the hot dry area of Turkey," Building and Environment 43 (2008): 1301-1309.

Ivan Margolius, Architects + Engineers = Structures (New York: John Wiley \& Sons,2002), 6. Donald Watson and Kenneth Labs, Climatic design: Energy-Efficient Building Principles and Practices (Columbus, OH: McGraw-hill, 1983),158-160.

Baruch Giovani, Climate consideration in building and urban design (New York: John Wiley \& Sons, 1998), 77-78.

Ghobadian Vahid, Climatic Analysis of the traditional Iranian building (Teheran:Uuniversity of Tehran press, 1998)

Randall Thomas and Max Fordhams, Environmental Design An introduction for architects and engineers (Oxford: Spon press, 1999), 9-11.

Donald Watson, Climatic design: Energy-Efficient Building Principles and Practices (Columbus, OH: McGraw-hill, 1983), 43-44.

M.N Bahadori, 'Passive cooling systems in Iranian architecture," Scientific American 238, No2 (1978): 144-154.

Francis Allard, Natural ventilation in buildings, A design handbook ( London: James \& James, 1998),235-241.

Donald Watson, Climatic design: Energy-Efficient Building Principles and Practices, (Columbus OH: McGraw-hill, 1983), 191-194.

Lechner Norbert, Heating, Cooling, and Lighting: Sustainable Design Methods for Architects (New York: John Wiley \& Sons, Inc, 2009), 288-294.

Donald Watson, Climatic design: Energy-Efficient Building Principles and Practices, ( Columbus OH: McGraw-hill,1983), 65-68.

Jan F. Kreider \& Ari Rabl, Heating and Cooling Of Buildings; Design for Efficiency, (Columbus OH: McGraw-Hill, 1994), 71-77. 
Allard, Francis. Natural ventilation in buildings, A design handbook. James \& James, 1998. Anon, CIBSE guide, volume A: Thermal properties of building structures. London: CIBSE, 1988. Bahadori, M.N. ' Passive cooling systems in Iranian architecture." Scientific American Vol. 238 (1978, No2 February): 144-154.

Fathy, Hassan. Natural energy and vernacular architecture; principles and examples with the reference to Hot Arid climates. Chicago and London: United nation University, University of Chicago press, 1986.

Giovani, Baruch. Climate consideration in building and urban design. New York: John Wiley \& Sons, 1998

Kreider, Jan F. and Ari Rabl. Heating and Cooling Of Buildings; Design for Efficiency. Columbus, OH: McGraw-Hill,1994.

Laustsen, Jens. Energy efficiency requirements in building codes, energy efficiency Policies for new buildings. Paris: International energy agency, 2008.

Manioglu, G. and Z. Yılmaz. "Energy efficient design strategies in the hot dry area of Turkey." Building and Environment 43 (2008): 1301-1309.

Margolius, Ivan. Architects + Engineers = Structures. New York: John Wiley \& Sons, 2002.

Norbert, Lechner. Heating, Cooling, and Lighting: Sustainable Design Methods for Architects. New York: John Wiley \& Sons,2009.

Thomas, Randall, and Max Fordhams. Environmental Design An introduction for architects and engineers. Oxford: Spon press, 1999.

Vahid, Ghobadian. Climatic Analysis of the traditional Iranian building. Teheran: University of Tehran press (in Persian), 1998.

Watson, Donald. Climatic design: Energy-Efficient Building Principles and Practices. Columbus, OH: McGraw-hill,1983.

http://www.engineeringtoolbox.com/thermal-conductivity-d_429.html 


\section{GEOMETRIJSKO VIRTUELNO MODELIRANJE: TRAPICHE I \\ MULTIMEDIJA. \\ GRAĐENJE ISTORIJSKOG NARATIVA (SERGIPE, BRAZIL)}

\section{Carla Maria Furuno Rimkus, Janaina Cardoso de Mello}

Računarske alatke se brzo razvijaju i neprekidno predstavljaju izazov profesionalcima koji se bave ovim tehnologijama, što dovodi do toga da se postigne nenadmašna produktivnost i odgovor, koji mogu da dosegnu do svih slojeva društva. Danas je taj izazov integrisanje ljudskog faktora u to tehnološko okruženje kako bi se brzo dobili rezultati pri niskim troškovima primene.

Ovaj rad predstavlja jednu studiju u toku o potencijalima ovih tehnologija da integrišu sisteme dokumentacije istorijske i tradiionalne građe, uz niske troškove sprovođenja, koja se odnosi na sistem za širenje i očuvanje istorijskog grada Laranjeirasa (Sergipe-Brazil), formiranjem specijalizovanog osoblja koje je obučeno da koristi digitalne tehnologije primenjive na istorijsku dokumentaciju. U ovom dinamičnom medijumu za razmenu informacija specifično se predlaže da se proceni uključena infrastruktura, kao i svi učesnici $\mathrm{u}$ tom procesu. Za ovu svrhu je odabran reprezentativni set arhitektonske istorije Laranjeiras grada (Sergipe, Brazil), nazvan Trapiche's Quadroon (Trapiche Kvaretron), koji je uspostavljen kao studija slučaja iz koje je namera da se formulišu smernice za sistematizaciju informacija koje se odnose na nasleđe tog grada.

KLJUČNE REČI: MULTIMEDIJA, INFORMACIJA, TEHNOLOGIJA, ISTORIJSKI GRAD

U SUSRET NOVIM PRILAZIMA PRETVARANJA PRINCIPA VERNAKULARNE AERHITEKTURE U ENERGETSKI EFIKASNE ZGRADE U TOPLIM I SUVIM KLIMAMA

\section{Yahya Lavafpour}

Zgrade mogu biti projektovane tako da zahevaju daleko manje energije nego što je današnji prosek. Smanjenje potrošnje energije zgrada u toplo-suvim klimamama korišćenjem prirodnih izvora energije da bi se obezbedila prijatna mikroklima predstavlja glavni problem kojim se bavi ova studija. U ovom radu se razmatraju strategije projektovanja u smislu iskoristljivosti energije koja se zasniva na pravilnom obliku zgrade, odabiru materijala i orijentacije i korišćenja prednosti strategija pasivnog hlađenja i ventilacije. Studija ima za cilj da pokaže da ideja o korišćenju prirodnih energetskih izvora i strategija pasivnog hlađenja potiče od vernakularnih principa (običajnih). 